Editorial

\title{
Types of Education, Achievement and Labour Market Integration over the Life Course
}

\author{
Irene Kriesi * and Juerg Schweri
}

Research and Development Department, Swiss Federal Institute for Vocational Education and Training, 3052 Zollikofen, Switzerland; E-Mails: irene.kriesi@sfivet.swiss (I.K.), juerg.schweri@sfivet.swiss (J.S.)

* Corresponding author

Submitted: 6 August 2019 | Published: 5 September 2019

\begin{abstract}
Over the last 15 years, research on the effects of different types of education on labour market integration and labour market outcomes has evolved. Whereas much of the early work analysed school-to-work transition outcomes, the focus of more recent studies has shifted to the relationship between educational achievement and mid- and long-term labour market outcomes. The overarching question of this body of research asks whether the allocation to different types of education leads to different skill sets, to different employment opportunities and to jobs offering unequal wages, job autonomy or job security. However, pivotal issues related to the comparison of vocational and general types of education or upper-secondary and tertiary-level qualification remain ambiguous and are hampered by a lack of suitable data and methodological problems. The aim of this issue is to further this debate and to provide more insights into the relationship between individual and contextual factors, allocation within the educational system, educational achievement and labour market outcomes over the life course. The 12 articles collected in this issue highlight the importance of focussing on the specific features and functions of different education tracks and programs, of applying data and methods suitable for such analyses and of considering the interplay of different determinants of education outcomes, such as social origin, gender or ethnicity.
\end{abstract}

\section{Keywords}

career trajectories; general education; labour market outcomes; returns to education; vocational education and training

Issue

This editorial is part of the issue "Types of Education, Achievement and Labour Market Integration over the Life Course", edited by Irene Kriesi (Swiss Federal Institute for Vocational Education and Training, Switzerland) and Juerg Schweri (Swiss Federal Institute for Vocational Education and Training, Switzerland).

(C) 2019 by the authors; licensee Cogitatio (Lisbon, Portugal). This article is licensed under a Creative Commons Attribution 4.0 International License (CC BY).

\section{Introduction}

In the face of high rates of youth employment in many Western countries, educational system characteristics have become the centre of attention in research as well as in educational policy. Some countries deal with the school-to-work transition primarily by diversifying postsecondary and tertiary education programmes, i.e. by offering different types of colleges and college degrees. Other countries also allow for different types of education on the upper-secondary level, typically with an emphasis on vocational education and training (VET). Countries with strong VET have been shown to fare better in integrating young people swiftly into the labour market after completion of education (Bol \& van de Werfhorst, 2016; Breen, 2005; de Lange, Gesthuizen, \& Wolbers, 2014; Ryan, 2001; Shavit \& Müller, 1998; van der Velden \& Wolbers, 2003; Winkelmann, 1996; Wolter \& Ryan, 2011; Zimmermann et al., 2013). This has been attributed to the high level of occupational specificity of VET, which increases initial productivity and reduces the immediate need of on-the-job training. As a result, the 
strengthening of VET has been proposed as a remedy for difficulties at labour market entry. However, the literature that goes beyond the question of unemployment at labour market entry reveals a more complex picture.

\section{Previous Research and Open Questions}

Country comparisons suggest that the effect of vocational education on job quality differs between countries. Vocational education reduces job mismatch more strongly in countries with a tight link between the educational system and the labour market and a high share of dual VET (e.g., Levels, van der Velden, \& Di Stasio, 2014; Wolbers, 2003). However, country comparisons are hampered by not being able to disentangle the effect of the national system, the type of education (vocational and general) and of differences in the student composition within VET and general education, which differs markedly between countries. In order to draw sound conclusions regarding the interplay of education and context factor, comparative data including skill measures would be useful.

The simple distinction between general education and VET does not take into account that general and vocational education programmes vary in their degree of occupational specificity (Backes-Gellner \& Geel, 2014; Forster \& Bol, 2017; Grønning, Kriesi, \& Sacchi, 2018; Lazear, 2009; Muja, Blommaert, Gesthuizen, \& Wolbers, 2019; Müller \& Schweri, 2015; Ormiston, 2014). Recent research has shown that occupation-specific skills facilitate labour market entry irrespective of whether they had been acquired in programmes typed as vocational or general (Eggenberger, Rinawi, \& Backes-Gellner, 2018; Forster \& Bol, 2017; Heijke \& Meng, 2011; Menze, 2017; Vogtenhuber, 2014). Furthermore, occupational specificity, and in particular firm-based VET, impacts labour market entry more strongly than job quality, such as the match between training and job content (Muja et al., 2019). However, this positive effect on finding a job is short-lived and does not translate into more positive employment outcomes in the long run (Lavrijsen \& Nicaise, 2017; Neyt, Verhaest, \& Baert, 2018; Verhaest, Lavrijsen, Van Trier, Nicaise, \& Omey, 2018).

The bulk of research comparing different types of education focuses on European countries. However, recent research shows that in some countries, VET is not so much an alternative to general upper-secondary education, but a stepping-stone to entering the labour market successfully. Corseuil, Foguel and Gonzaga (2019) show that the apprenticeship program in Brazil, adopted at a large scale after the year 2000, increased employment in permanent jobs and educational attainment of young workers compared to their peers who entered the labour market via temporary jobs without apprenticeship. Field, Linden, Malamud, Rubenson and Wang (2019), who randomly allocated scarce slots for oversubscribed vocational schools in Mongolia, find sizeable positive employment and earnings effects for those students who were admitted to a vocational school.
There is some evidence that VET falls short in teaching numeracy and literacy skills, thus contributing to increased achievement inequality (e.g., Brunello \& Rocco, 2015; van de Werfhorst \& Mijs, 2010). In the same vein, some studies suggest that there may be a trade-off between a smooth labour market entry and long-term disadvantages of vocational compared to general skills regarding employment and wages (Forster, Bol, \& van de Werfhorst, 2016; Hanushek, Schwerdt, Wössmann, \& Zhang, 2017; Korber \& Oesch, 2019; Lavrijsen \& Nicaise, 2017). The results on the timing and magnitude of the disadvantage of VET in the later career are, however, controversial, and some studies find no disadvantages for VET graduates at all (Hall, 2016; Malamud \& Pop-Eleches, 2010; Schweri, Eymann, \& Aepli, 2019). Furthermore, there is some evidence of considerable heterogeneity between fields, as Espinoza and Speckesser (2019) show for Great Britain, where workers with higher vocational education in STEM fields receive considerably higher returns than many university graduates.

Some studies imply that the relationship between skill specificity and labour market outcomes differs between upper-secondary and tertiary education (Brunello \& Rocco, 2015; Culpepper, 2007). A recent study by Bol, Ciocca Eller, van de Werfhorst and DiPrete (2019) shows, for example, that a strong link between the training programme and the labour market generally leads to higher wages for tertiary-level graduates. For workers with upper-secondary education only, this relationship only manifests itself in countries with a highly occupation-specific dual training system.

In summary, it remains unclear whether and to what extent different types of education and skills at the upper-secondary and tertiary level matter for educational achievement and long-term labour market outcomes beyond the school-to-work transition. Furthermore, the possible mechanisms explaining different career outcomes have been little investigated. Given the rapid changes in skill demand, triggered by technological developments, more knowledge on the sustainability of different types of education and skills is required.

\section{Aim of and Contributions to the Thematic Issue}

The aim of this thematic issue is to shed more light on the relationship between educational attainment, employment and job quality beyond labour market entry and its context-dependency. The issue includes 12 contributions which focus on different countries-including Germany, Switzerland, Austria, Great Britain, Spain and Norwayand types of education. They also vary regarding the outcomes of interest and the studied context factors, which include work tasks, socio-economic background, gender, migration background, birth cohorts and institutional contexts.

Several of the contributions look at facets of educational attainment. Grønning and Trede (2019) analyse 
whether VET outcomes are related to labour market segments. Using the example of Swiss health care, they show that apprenticeship training is affected by patterns of labour market segmentation. The allocation of apprentices to a specific training segment affects their chances to enter tertiary-level education after completion of upper-secondary VET. The contribution highlights the heterogeneity of VET and shows that the early allocation within the training system may have long-lasting consequences for career and income prospects.

Zimmermann and Seiler (2019) identify five dominant educational pathways in Switzerland-vocational, vocational \& tertiary, specialized secondary \& tertiary, academic mixed and academic - which determine young people's labour market outcomes in adulthood. The authors show, firstly, that net of ability, SES and gender strongly influence the chosen pathway. Secondly, the five pathways lead to markedly different occupational status and income prospects. The findings also highlight that pathways, which include secondary or tertiary-level vocational education, lead to considerably lower income prospects for women than for men.

Bratsberg, Nyen and Raaum (2019) analyse whether education programmes targeted at adults in Norway succeed in reducing the correlation of parental education and their children's educational attainment at the uppersecondary level. Using register data, they show that substantial proportions of Norwegian men and women still complete upper-secondary education after age 25 . Four main routes for adults to an upper-secondary degree all contribute to this result. Even in these programs, the selection of participants is biased towards individuals with higher parental education but less so than in education programmes before 25 . Therefore, adult vocational qualifications reduce the overall social gradient quite substantially, with the "experience-based route" to vocational qualifications being most effective.

Using a qualitative approach, Barroso-Hurtado and Chan (2019) compare the perspectives of Austrian and Spanish young adults who had entered lifelong learning programmes. Drawing on the concept of transition regimes (Walther, 2017), the authors analyse the relationship between institutional context characteristics and young people's transition experiences and life plans. The results illustrate that the outcomes of educational programmes, including the opportunities, perspectives and support they provide, vary considerably between the employment-centred transition regime in Austria and the under-institutionalized transition regime in Spain, which strongly relies on family support and informal networks.

Income is an important indicator of job quality. Consequently, several of the contributions in this issue look at the income prospect of different types of education. Rohrbach-Schmidt (2019) investigates the relationship between the level of education, work tasks and income by comparing German workers with university and VET degrees within the same occupational group. The re- sults show that employees with university degrees complete higher shares of abstract and lower shares of manual tasks compared to employees with VET degrees. This affects income differences between the two groups because abstract tasks are related to higher wages, more so than manual tasks, on average. Yet, non-routine manual tasks are rewarded with wage gains in highly specific manual occupations. This indicates that the occupational specificity of tasks matters in addition to the task types.

Sander and Kriesi (2019) compare the long-term wage prospects of upper-secondary and tertiary-level VET in Switzerland. Based on a quasi-panel approach, the contribution estimates that on average and across the entire working life, the completion of a tertiary-level vocational degree leads to eleven per cent higher returns. However, the wage gains related to tertiary-level degrees differ considerably between occupational training groups. In line with the assumptions of the skill-biased technological change approach, returns to tertiary-level vocational training increase with increasing shares of analytic, interactive but also manual non-routine tasks, which are difficult to execute solely with machines.

Glauser, Zangger and Becker (2019) compare wages of bachelor and master degree holders in Switzerland five years after graduation. They focus on cohort differences and ask whether the institutionalization of bachelor's degrees after the Bologna reform affected the returns to this type of education compared to a master's degree. They find a persistent income advantage of labour market participants who completed a master rather than a bachelor's degree, which stabilized across birth cohorts after the introduction of the latter in 2004. The results also confirm findings from previous research, which showed that the income prospects of university graduates differ considerably by field of study and are highest for economics, medicine and pharmacy.

The contribution of Luchinskaya and Dickinson (2019) distinguishes between different types of further training after completion of full-time education and investigates their relationship with wages. The authors show that the reasons for further training differ between workers with different occupational status. Those with routine occupations more often undergo training in order to get started in their job or to do health and safety training, whereas workers in intermediate or higher managerial and professional occupations more often undertook training to improve their skills. Furthermore, the findings reveal that not all types of training lead to higher wages, and some types, such as health and safety training, are even associated with wage loss. Types of training which help to maintain or improve skills are associated with small wage gains manifesting themselves after several years only. Workers in lower-level occupations are not only less likely to participate in training, but they are also more likely to have done a type of training that is not associated with wage gains.

Diverging from the bulk of previous research comparing VET with general education, Korber (2019) inves- 
tigates the income and employment prospects of workers with upper-secondary VET and compulsory education in Switzerland and Great Britain-two countries which differ regarding the specificity and standardization of their VET systems. By using a pseudo-cohort approach, the author shows that in both countries, uppersecondary VET provides an employment and wage advantage over compulsory education and on-the-job training only. However, the employment advantage is considerably larger in Great Britain than in Switzerland, confirming that the relationship between the type of education and labour market outcome is dependent on the context.

Employment is also the focus of Kratz, Patzina, Kleinert and Dietrich's (2019) contribution. It analyses changes in employment patterns of workers with general and vocational education across cohorts. The findings imply that the employment advantage of people with VET, which was consistently found in previous research for early working life, is larger for younger cohorts than for those born before 1980. Furthermore, a part of the employment disadvantage found for vocationally trained men in their late working life may be attributed to poor health-possibly induced by the more demanding working conditions in jobs for vocationally trained men. The findings of this contribution reveal the limits of cross-sectional analysis. They highlight that previous evidence, showing that individuals with general education "overtake" those with vocational education late in their careers (Hanushek et al., 2017), necessarily relies on few and relatively old cohorts, whose experiences may differ from those of workers born later.

Wicht, Müller, Haasler and Nonnenmacher (2019) broaden the perspective on job quality by considering not only wages but also job security, job autonomy and the match between abilities and demand. Furthermore, and unlike most studies, they are able to control for literacy skills by using the PIAAC data. Their findings pertaining to Germany show that workers with initial VET earn less and experience less job autonomy compared to those with advanced VET or academic qualifications. Whereas workers with advanced VET also had lower earnings compared to their academically educated counterparts, their level of job autonomy was comparable. In sum, the contribution shows that job quality differs between workers with different types of education, even after taking basic skills into account.

Naseem (2019) compares the educational achievement and labour market integration of British-born female graduates with Pakistani and Algerian parents. By using a qualitative approach, the contribution reveals how the intersection of gender, ethnicity and socioeconomic background shapes the choice of higher education institution and subsequent career trajectories. In order to comply with cultural and religious gender roles, women had to compromise regarding their choice of university. Furthermore, both groups of women-and particularly those from working-class families-faced prejudice and disadvantages at labour market entry but man- aged to improve their position over time by building their "identity capital" and perceived employability. The contribution thus highlights how long-term labour market outcomes depend on a complex interplay of types of education, gender, gender-role constraints and individual agency.

\section{Conclusions}

Taken together, the contributions in this issue provide new insights into the complex relationship between types of education, educational achievement, individual and contextual factors and labour market outcomes at various stages in the life course. The results highlight, on the one hand, that different types of education go along with different employment opportunities and job quality in the long-run, and even for individuals working within the same occupation (Glauser et al., 2019; Korber, 2019; Rohrbach-Schmidt, 2019; Wicht et al., 2019). On the other hand, several contributions provide evidence that-despite these differences-there is considerable heterogeneity within types of education. VET, higher education as well as further training after labour market entry are linked to heterogeneous outcomes, which differ markedly by the chosen occupational field/level or type of training (Bratsberg et al., 2019; Grønning \& Trede, 2019; Luchinskaya \& Dickinson, 2019; Sander \& Kriesi, 2019). Furthermore, the contributions on this issue show that there is interplay between types of education and ascribed characteristics, such as gender, social origin or migration background. Occupational outcomes tied to certain types of education differ for men and women, people with and without a migration background (Naseem, 2019; Zimmermann \& Seiler, 2019) as well as by the national context (Barroso-Hurtado \& Chan, 2019; Korber, 2019). In a similar vein, educational attainment in adulthood and the concomitant labour market outcomes are related to individuals' social background and occupational status (Bratsberg et al., 2019; Luchinskaya \& Dickinson, 2019). Last but not least, two cohort comparisons provide the first tentative evidence that the relationship between types of education and labour market outcomes may have changed over time (Glauser et al., 2019; Kratz et al., 2019). However, the reasons are difficult to pinpoint with the available data. Changes across cohorts may be due to changing education contents and teaching methods as well as due to changes in the labour market structure.

Despite providing new insights, the contributions of this issue also highlight that many open questions and challenges remain. This is partly due to a lack of longitudinal data, which would allow the observation of an individual's entire working life. A useful example is the Norwegian register data used by Bratsberg et al. (2019). Thanks to the full population information, this contribution is able to trace all adults and investigate their educational or occupational attainment over a period of 15 years. Furthermore, this kind of data also allows a 
comparison of birth cohorts and thus the investigation of changes over time.

However, register data alone does not solve the pivotal problem of causality, which hampers the vast majority of studies in this field. In order to identify the advantages, disadvantages and trade-offs between different types of education and to formulate sustainable policy recommendations, it would be necessary to pinpoint the causal effects of education. The selection of individuals with different unobserved characteristics into different types of education severely limits the comparability of outcomes between different education groups. Such selection processes differ between education programs, countries, and across time. One important improvement are indicators of individual ability, which have hitherto not been available in most large-scale longitudinal data sets. If such data existed for several countries, it could help to disentangle the role of the institutional context vis-à-vis the skills composition of groups of individuals with certain types of education.

Another issue, which would shed more light on the advantages and disadvantages of VET versus general education, pertains to the heterogeneity of these types of education as well as to country differences regarding their characteristics. As recent research has shown, the distinction between broad types of education masks the large differences within types (Forster \& Bol, 2017; Grønning et al., 2018). There is some early evidence that such differences go along with unequal labour market outcomes between social groups (Grønning, Kriesi, \& Sacchi, 2019; Zimmermann \& Seiler, 2019). Further research is needed on the measurement and conceptualization of such differences, on their possible effects on educational and labour market outcomes as well as on the intersectionality of educational characteristics and social group membership, such as social origin, gender or ethnicity.

\section{Acknowledgments}

We would like to thank the numerous reviewers, who dedicated their time and expertise, for their valuable feedback on the articles submitted to this issue.

\section{Conflict of Interests}

The authors declare no conflict of interests.

\section{References}

Backes-Gellner, U., \& Geel, R. (2014). A comparison of career success between graduates of vocational and academic tertiary education. Oxford Review of Education, 40(2), 266-291.

Barroso-Hurtado, D., \& Chan, R. (2019). Why enrol in a lifelong learning programme? A comparative study of Austrian and Spanish young adults. Social Inclusion, 7(3), 110-121.
Bol, T., Ciocca Eller, C., van de Werfhorst, H. G., \& DiPrete, T. A. (2019). School-to-work linkages, educational mismatches, and labor market outcomes. American Sociological Review, 84(2), 275-307.

Bol, T., \& van de Werfhorst, H. (2016). Measuring educational institutional diversity: Tracking, vocational orientation and standardisation. In A. Hadjar \& C. Gross (Eds.), Education systems and inequalities: international comparison (pp. 73-93). Bristol: Policy Press.

Bratsberg, B., Nyen, T., \& Raaum, O. (2019). Adult vocational qualifications reduce the social gradient in education. Social Inclusion, 7(3), 95-109.

Breen, R. (2005). Explaining cross-national variation in youth unemployment. Market and Institutional Factors. European Sociological Review, 21(2), 125-134.

Brunello, G., \& Rocco, L. (2015). The effects of vocational education on adult skills and wages: What can we learn from PIAAC? (OECD Social, Employment and Migration Working Paper 168). Paris: OECD. https:// dx.doi.org/10.1787/5jrxfmjvw9bt-en

Corseuil, C. H., Foguel, M. N., \& Gonzaga, G. (2019). Apprenticeship as a stepping stone to better jobs: Evidence from Brazilian matched employer-employee data. Labour Economics, 57, 177-194.

Culpepper, P. D. (2007). Small states and skill specificity. Austria, Switzerland, and interemployer cleavages in coordinated capitalism. Comparative Political Studies, 40(6), 611-637.

de Lange, M., Gesthuizen, M., \& Wolbers, M. H. J. (2014). Youth labour market integration across Europe The impact of cyclical, structural, and institutional characteristics. European Societies, 16(2), 194-212.

Eggenberger, C., Rinawi, M., \& Backes-Gellner, U. (2018). Occupational specificity: A new measurement based on training curricula and its effect on labor market outcomes. Labour Economics, 51, 97-107.

Espinoza, H., \& Speckesser, S. (2019). A comparison of earnings related to higher level vocational/technical and academic education (NIESR Discussion Paper 502). London: National Institute of Economic and Social Research.

Field, E. M., Linden, L. L., Malamud, O., Rubenson, D., \& Wang, S.-Y. (2019). Does vocational education work? Evidence from a randomized experiment in Mongolia (NBER Working Paper 26092). Cambridge, MA: National Bureau of Economic Research.

Forster, A. G., \& Bol, T. (2017). Vocational education and employment over the life course using a new measure of occupational specificity. Social Science Research, 70, 176-197.

Forster, A. G., Bol, T., \& van de Werfhorst, H. G. (2016). Vocational education and employment over the life cycle. Sociological Science, 3, 473-494.

Glauser, D., Zangger, C., \& Becker, R. (2019). The signal and the noise: The impact of the Bologna process on Swiss graduates' monetary returns to higher education. Social Inclusion, 7(3), 154-176.

Grønning, M., Kriesi, I., \& Sacchi, S. (2018). Institutional 
dimensions of Swiss vocational education and training: Measures of standardisation, differentiation and vocational specificity in Swiss upper secondary vocational education and training. Zollikofen: Swiss Federal Institute for Vocational Education and Training.

Grønning, M., Kriesi, I., \& Sacchi, S. (2019). Skill specificity of upper-secondary training occupations and the gender pay gap (SFIVET Working Paper). Zollikofen: Federal Institute for Vocational Education and Training.

Grønning, M., \& Trede, I. (2019). Does it matter where they train? Transitions into higher education after VET and the role of labour market segments. Social Inclusion, 7(3), 65-78.

Hall, C. (2016). Does more general education reduce the risk of future unemployment? Evidence from an expansion of vocational upper secondary education. Economics of Education Review, 52, 251-271.

Hanushek, E. A., Schwerdt, G., Wössmann, L., \& Zhang, L. (2017). General education, vocational education, and labor-market outcomes over the lifecycle. Journal of Human Resources, 52(1), 48-87.

Heijke, H., \& Meng, C. (2011). The effects of higher education programme characteristics on the allocation and performance of the graduates. Education Economics, 19(1), 1-27.

Korber, M. (2019). Does vocational education give a labour market advantage over the whole career? A comparison of the United Kingdom and Switzerland. Social Inclusion, 7(3), 202-223.

Korber, M., \& Oesch, D. (2019). Vocational versus general education: Employment and earnings over the life course in Switzerland. Advances in Life Course Research, 40, 1-13.

Kratz, F., Patzina, A., Kleinert, C., \& Dietrich, H. (2019). Vocational education and employment: Explaining cohort-variations in life course patterns. Social Inclusion, 7(3), 224-253.

Lavrijsen, J., \& Nicaise, I. (2017). Returns on vocational education over the life cycle: Between immediate labour market preparation and lifelong employability. International Review of Education, 63(2), 257-280.

Lazear, E. P. (2009). Firm-specific human capital: A skill-weights approach. Journal of Political Economy, 117(5), 914-939.

Levels, M., van der Velden, R., \& Di Stasio, V. (2014). From school to fitting work: How education-to-job matching of European school leavers is related to educational system characteristics. Acta Sociologica, 57(4), 341-361.

Luchinskaya, D., \& Dickinson, P. (2019). 'Virtuous' and 'vicious' circles? An exploratory analysis of adults' participation in different types of training in the UK and its association with wages. Social Inclusion, 7(3), 177-201.

Malamud, O., \& Pop-Eleches, C. (2010). General education versus vocational training: Evidence from an economy in transition. The Review of Economics and Statistics, 92(1), 43-60.
Menze, L. (2017). Horizontale und vertikale Adäquanz im Anschluss an die betriebliche Ausbildung in Deutschland [Horizontal and vertical matches after apprenticeship training in Germany]. KZfSS Kölner Zeitschrift für Soziologie und Sozialpsychologie, 69(1), 79-107.

Muja, A., Blommaert, L., Gesthuizen, M., \& Wolbers, M. $H$. (2019). The role of different types of skills and signals in youth labor market integration. Empirical Research in Vocational Education and Training, 11(1), 6-29.

Müller, B., \& Schweri, J. (2015). How specific is apprenticeship training? Evidence from inter-firm and occupational mobility after graduation. Oxford Economic Papers, 67(4), 1057-1077.

Naseem, J. (2019). "I didn't have the luxury to wait": Understanding the university-to-work transition among second-generations in Britain. Social Inclusion, 7(3), 270-281.

Neyt, B., Verhaest, D., \& Baert, S. (2018). The impact of dual apprenticeship programs on early labour market outcomes: A dynamic approach (IZA Discussion Paper 12011). Bonn: IZA Institute of Labor Economics.

Ormiston, R. (2014). Worker displacement and occupation-specific human capital. Work and Occupations, 41(3), 350-384.

Rohrbach-Schmidt, D. (2019). Putting tasks to the test: The case of Germany. Social Inclusion, 7(3), 122-135.

Ryan, P. (2001). The school-to-work transition: A crossnational perspective. Journal of Economic Literature, 39(March), 34-92.

Sander, F., \& Kriesi, I. (2019). Medium and long-term returns to professional education in Switzerland: Explaining differences between occupational fields. Social Inclusion, 7(3), 136-153.

Schweri, J., Eymann, A., \& Aepli, M. (2019). Horizontal mismatch and vocational education (Working Paper 160). Zurich: University of Zurich, Department of Business Administration.

Shavit, Y., \& Müller, W. (1998). From school to work. A comparative study of educational qualifications and occupational destinations. Oxford: Clarendon Press.

Van der Velden, R. K. W., \& Wolbers, M. H. J. (2003). The integration of young people into the labour market: The role of training systems and labour market regulation. In W. Müller \& M. Gangl (Eds.), Transitions from education to work in Europe. The integration of youth into EU labour markets (pp. 186-211). Oxford: Oxford University Press.

Van de Werfhorst, H. G., \& Mijs, J. J. B. (2010). Achievement inequality and the institutional structure of educational systems: A comparative perspective. Annual Review of Sociology, 36, 407-428.

Verhaest, D., Lavrijsen, J., Van Trier, W., Nicaise, I., \& Omey, E. (2018). General education, vocational education and skill mismatches: Short-run versus longrun effects. Oxford Economic Papers, 70(4), 974-993.

Vogtenhuber, S. (2014). The impact of within country heterogeneity in vocational specificity on initial job 
matches and job status. Journal of Vocational Behavior, 85(3), 374-384.

Walther, A. (2017). Support across life course regimes. A comparative model of social work as construction of social problems, needs, and rights. Journal of Social Work, 17(3), 277-301.

Wicht, A., Müller, N., Haasler, S., \& Nonnenmacher, A. (2019). The interplay between education, skills, and job quality. Social Inclusion, 7(3), 254-269.

Winkelmann, R. (1996). Employment prospects and skill acquisition of apprenticeship-trained workers in Germany. Industrial \& Labor Relations Review, 49(4), 658-672.

Wolbers, M. (2003). Job mismatches and their labour market effects among school leavers in Europe. In I. Kogan \& W. Müller (Eds.), School-to-work transitions in Europe: Analyses of the EU LFS 2000 ad hoc module (pp. 89-120). Mannheim: Mannheimer Zentrum für Europäische Sozialforschung.

Wolter, S. C., \& Ryan, P. (2011). Apprenticeship. In E. Hanushek \& F. Welch (Eds.), Handbook of the economics of education (Vol. 3, pp. 521-576). Amsterdam: Elsevier.

Zimmermann, B., \& Seiler, S. (2019). The relationship between educational pathways and occupational outcomes at the intersection of gender and social origin. Social Inclusion, 7(3), 79-94.

Zimmermann, K. F., Biavaschi, C., Eichhorst, W., Giulietti, C., Kendzia, M. J., Muravyev, A., . . Schmidl, R. (2013). Youth unemployment and vocational training. Foundations and Trends $^{\circledR}$ in Microeconomics, 9(1/2), 1-157.

\section{About the Authors}

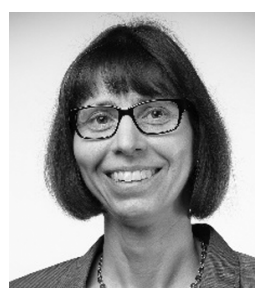

Irene Kriesi is a Professor at the Swiss Federal Institute for Vocational Education and Training and co-head of the research area on "Strategic planning of the VPET system". She holds a doctorate in Sociology from the University of Zurich. Her research interests include educational trajectories, schoolto-work transitions, occupational careers, and social inequality, with a specific focus on gender inequalities and vocational education and training.

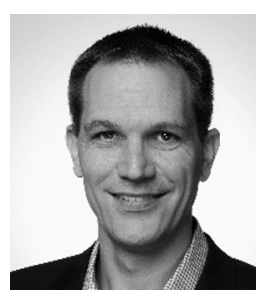

Juerg Schweri is a Professor at the Swiss Federal Institute for Vocational Education and Training and co-head of the research area on "Strategic planning of the VPET system". He holds a doctorate in Economics from the University of Bern. His research areas are the economics of education and labour economics. His specific interests include firms' training behaviour, individuals' education choices and pathways, and occupational careers with a particular focus on vocational education and training. 